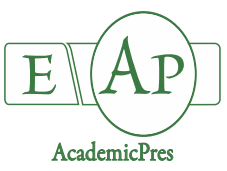

Berca M et al. (2021)

Notulae Botanicae Horti Agrobotanici Cluj-Napoca

Volume 49, Issue 2, Article number 12309

DOI: $10.15835 /$ nbha49212309

Research Article

\title{
Winter wheat crop water consumption and its effect on yields in southern Romania, in the very dry 2019-2020 agricultural year
}

\section{Mihai BERCA ${ }^{1 *}$, Valentina-Ofelia ROBESCU ${ }^{2}$, Roxana HOROIAS ${ }^{3}$}

\author{
${ }^{1}$ University of Agronomic Sciences and Veterinary Medicine of Bucharest, Faculty of Management, 59 Marasti Blvd., District 1, \\ Bucharest,Romania; berca.mihai@managusamv.ro ("corresponding author) \\ ${ }^{2}$ Valahia University of Targoviste, Faculty of Economics, 2 Regele Carol I Blvd., 130024, Targoviste City, \\ Romania;robescu_ofelia@yahoo.com \\ ${ }^{3}$ Probstdorfer Saatzucht Romania SRL, R\&D Department, 20 Siriului Street, 014354, District 1, Bucharest, \\ Romania; roxana.horoias@gmail.com
}

\begin{abstract}
Researches on winter wheat in the south part of Romanian Plain during the dry years 2019 and 2020 have been focused on the crop water consumption issue in excessive conditions of air and soil drought. The wheat crop water consumption in the research sites (Calarasi and Teleorman counties), for the entire vegetation period, autumn - spring - summer, is between 1000 and $1050 \mathrm{~m}^{3}$ of water for each ton of wheat produced. Only in the spring-summer period, the wheat extracts a quantity of about $5960 \mathrm{~m}^{3}$ ha $\mathrm{a}^{-1}$, i.e. $851 \mathrm{~m}^{3}$ $\mathrm{t}^{-1}$. The useful water reserve is normally located at about $1500 \mathrm{~m}^{3} / \mathrm{ha}^{-1}$, at a soil depth of $0-150 \mathrm{~cm}$. In the spring of 2020, it has been below $400 \mathrm{~m}^{3} \mathrm{ha}^{-1}$, so that at the beginning of May the soil moisture had almost reached the wilting coefficient (WC). Wheat plants have been able to survive the thermal and water shock of late spring - early summer, due to enhanced thermal alternation between air and soil. For a period of about 34 days, this alternation brought the plants 1-1.5 mm water, i.e. approximately $442 \mathrm{~m}^{3} \mathrm{ha}^{-1}$, which allowed the prolongation of the plant's agony until the rains of the second half of May. Yields have been, depending on the variety, between 1500 and $3000 \mathrm{~kg} \mathrm{ha}^{-1}$, in average, covering only $60 \%$ of the crop costs. Other measures to save water in the soil have also been proposed in the paper.
\end{abstract}

Keywords: abiotic stress; drought; evapotranspiration; high temperatures; water consumption; winter wheat; yields

\section{Introduction}

Climate changes, especially the rising temperatures and the declining rainfall volume, have a major influence on crops, causing an imbalance in soil water supply (Ray et al., 2018; Shayanmehr et al., 2020). Chowdhury et al. (2016) developed a study on crops' water needs for the period 2011-2050, based on four scenarios related to temperatures and precipitation.

Although resistant to abiotic stresses, wheat crop becomes sensitive when high temperatures persist for several days, especially when the water is missing too (Pradhan et al., 2012; He et al., 2014; Zampieri et al., 2017). According to several authors, the stress caused by drought and heat affects both the physiology (Duggan

Received: 12 Mar 2021. Received in revised form: 17 Jun 2021. Accepted: 17 Jun 2021. Published online: 21 Jun 2021.

From Volume 49, Issue 1, 2021, Notulae Botanicae Horti Agrobotanici Cluj-Napoca journal uses article numbers in place of the traditional method of continuous pagination through the volume. The journal will continue to appear quarterly, as before, with four annual numbers. 
et al., 2020) and the yields of wheat plants (Giunta et al., 1993; Jamieson et al., 1995; Yu et al., 2018; Qaseem et al., 2019; Anwaar et al., 2020). Some agrotechnics may partially reduce the negative effects of climate change, with beneficial consequences on crop yields (Zhang et al., 2009; Sang et al., 2016; Khan et al., 2020; Shen et al., 2020).

In literature is mentioned a wheat crop water consumption between 748 and $1400 \mathrm{~m}^{3} / \mathrm{t}^{-1}$ of grains obtained (Erie et al., 1981; Li et al., 2008; Muratoglu, 2020). Most researchers concluded that the wheat consumption is always around $1000 \mathrm{~m}^{3}$ water $/ \mathrm{t}^{-1}$ grains (ACES, 2018; Nulsen and Baxter, 1987; Scott et al., 2019a; Scott et al., 2019b), almost 3 times more than in the case of maize and 7-8 times more than in the case of potatoes (Berca, 2011).

However, there are also many authors (Berca, 2011; Fan et al., 2013; Muratoglu, 2020) who believe that through crop technologies, varieties, fertilizers, tillage and preceding plants, the water consumption of the crop can be reduced up to $800 \mathrm{~m}^{3} / \mathrm{t}^{-1}$ wheat and even less, but not below $600 \mathrm{~m}^{3} / \mathrm{t}^{-1}$.

The problems related to the supply of water to plants through soil are extremely complex, and the figures involving the actual water consumption of plants can only be calculated with low probabilities (high risks) due to the enormous number of factors present in this system, to the interactions among them and to their frequent vector changes, which do not allow their measurement through research, nor the quantification of their influence. Therefore, the advanced figures on water demand and the take-up model can only be estimated, with probabilities not exceeding $80 \%$, in the happiest case. At an estimated consumption of $1000 \mathrm{~m}^{3} / \mathrm{t}^{-1}$ wheat, it becomes clear that this requirement can be at the same time 800 or $1200 \mathrm{~m}^{3} / \mathrm{t}^{-1}$.

At a production of $6 \mathrm{t}$ wheat $/ \mathrm{ha}^{-1}$, the differences could be of $\pm 2400 \mathrm{~m}^{3} / \mathrm{ha}^{-1}$, i.e. $240 \mathrm{~mm}$ precipitation, where they are the only source of soil supply. It is unlikely that, with the current research methodologies, we will obtain more precise results, but only clearer trends, evaluations, which will allow us technological performances.

Knowing the water consumption of plants starts from the two parameters of consumption (evaporation - E and transpiration - T), together are known as evapotranspiration (ET), which can be calculated in many ways (Hobbs and Krogman, 1974; Tyagi et al., 2000; Patel et al., 2010; Drerup et al., 2017; Cui et al., 2018; da Silva et al., 2020). The two components can be determined separately or together.

Evaporation (E) refers to the loss of water from the soil where the crop is placed. Specific literature has been used and methods for determining transpiration (T) (Fletcher et al., 2018) or evapotranspiration (Lu et al., 2018; Kenjabaev et al., 2020) in wheat have been assimilated. Using the CROPWAT model (Smith et al., 2002) and the Mark Marsalis model (ACES, 2018), we were able to simulate the required daily plant consumption over the entire vegetation period.

\section{Materials and Methods}

\section{Description of study sites}

Water consumption is highly correlated with pedoclimatic factors, which is why the methodology took them into account (Blaga et al., 2005; Hoban, 2008; Cojocaru, 2016). The research has been conducted in the south part of Romania, in Romanian Plain, generally characterized by a semi-arid to arid climate.

The studies and observations have been carried out in two localities: Calomfiresti - Teleorman county $\left(43.92^{\circ}\right.$ lat. N, $25.35^{\circ}$ long. E) and Modelu - Calarasi county $\left(44.20^{\circ}\right.$ lat. N, $27.39^{\circ}$ long. E). The research focused on wheat crop and aimed, in addition to a potential water consumption for optimal yields, the real situation. The distance between the two research points is around $350 \mathrm{~km}$. Cultivated soils were leached chernozems, with about 30-32\% clay and 3.5\% humus. Soils are hardly permeable to water and have no contact with the groundwater. Deep water leaks weren't found. In Calarasi the experiments have been located on a slightly carbonated chernozem, with about $24-25 \%$ clay and $3.1-3.2 \%$ humus, with a better permeability and with contact with groundwater at precipitation over $100 \mathrm{~mm}$. 
In Teleorman it rains, on average for 30 years, $543.9 \mathrm{~mm}$, i.e. $5439 \mathrm{~m}^{3}$ of water $/ \mathrm{ha}^{-1}$, while in Calarasi it rains $490.9 \mathrm{~mm}$, i.e. $4909 \mathrm{~m}^{3} / \mathrm{ha}^{-1}$, with $530 \mathrm{~m}^{3} / \mathrm{ha}^{-1}$ less $(-10 \%)$. Hence the more arid regime.

The water reserve on the depth of 1.5 meters has been, in autumn, of only $1300 \mathrm{~m}^{3} \mathrm{ha}^{-1}$ at Calomfiresti and $530 \mathrm{~m}^{3} \mathrm{ha}^{-1}$ at Modelu, very small, the deficiency being accentuated in winter 2020-spring 2021. Tracking the balance of water in soil and plants is a complex operation, for which there is currently no simple equipment to perform it. Therefore, to establish the water reserve in the soil, the classic method has been used, drying the soil in an oven, on well-defined cylinders. The determinations were performed in autumn, at depths from 30 to $30 \mathrm{~cm}$, up to $150 \mathrm{~cm}$. Water inflows and outflows from the system, which allowed us to calculate the dynamics of the reserve, have been performed by interpreting data taken from weather stations - rainfall, temperature, air humidity, wind speed and insolation (model by Nulsen and Baxter, 1987).

\section{Evaluated parameters}

The models developed in France by Jacques Beauchamp (2006), who also worked on very similar soils, were also used. The water balance of the soil is given by:

a) falling precipitation;

b) actual evapotranspiration (AET);

c) water losses through horizontal and vertical leakages (on slopes and drains).

Taking into account the fact that due to the severe droughts and the flat terrain there are no leaks at the surface and in depth, the water balance is limited only to precipitation $(\mathrm{P})$ and actual evapotranspiration (AET). As precipitation is measurable, the AET and potential evapotranspiration (PET) remain to be calculated. For this there are several empirical formulas, such as those of Thornthwaite, Penman or Turc (Beauchamp, 2006).

According to Turc, the formula for calculating the actual evapotranspiration is:

$$
\operatorname{AET}(\mathrm{mm} / \text { year })=\frac{P}{\left(0.9+\frac{P^{2}}{L^{2}}\right)^{\frac{1}{2}}}
$$

where: $L=0,05 t^{3}+25 t+300$

$\mathrm{P}=$ precipitation $(\mathrm{mm})$

$\mathrm{t}=$ temperature $\left({ }^{\circ} \mathrm{C}\right)$

Potential evapotranspiration (PET) expresses the potential consumption of the crop. When the water doesn't fall below $30 \%$ of the active humidity range (AHR), it is calculated using Thornthwaite's formula. The productive component of AET or PET is transpiration $(\mathrm{T})$, which correlates with evapotranspiration $(\mathrm{E})$ in a ratio $\frac{T}{E}=\frac{85}{15}=5.7$, with variations between 2.0 and 9.0. The degree of soil covered by the crop increases or, on the contrary, reduces this ratio (Scradeanu and Gheorghe, 2007). The ET coefficient represents the amount of water consumed by the plant in order to obtain one $\mathrm{kg}$ of dry matter or one $\mathrm{kg}$ of actual yield, in which case it may be about the $\mathrm{R}$ coefficient $(\mathrm{R}=$ real).

\section{Statistical analysis}

To create the functions of wheat consumption during its vegetation period, the statistical calculation of correlations has been used, in order to determine the total or partial consumption (in stages) for an optimal situation and then comparisons with the concrete situation of the very dry agricultural year 2019-2020 have been made. 


\section{Results and Discussion}

Based on the data of the researchers cited above and many others (Allen et al., 1998; Moutonnet, 2002; MMGA, 2005), but also using our own determinations on rainfall and soil humidity dynamics, as well as the data provided by the National Administration of Meteorology, a model of wheat crop water consumption (Figure 1) and a model of water absorption from the soil for a yield of about 6.5-7.0 tons, achievable in the Romanian agricultural area, have been developed. Mathematically, the theory of probability has been used, using the Table Curve 2D program for calculating the time functions during the wheat vegetation period, the water consumption and its uptake from the soil. That allowed us to obtain extremely complex functions with a high degree of probability (low, insignificant risk) starting from the collected data, combined with those personally measured. For the calculation of the water consumed during certain vegetation periods, the integral of the function for that period and for the entire vegetation period has been calculated. The vegetation period of the wheat was of 273 days (on average), so that:

$$
\int_{1}^{273} f x(d x)=753 \mathrm{~mm}=7530 \mathrm{~m}^{3} \mathrm{ha}^{-1} \text { wheat }
$$

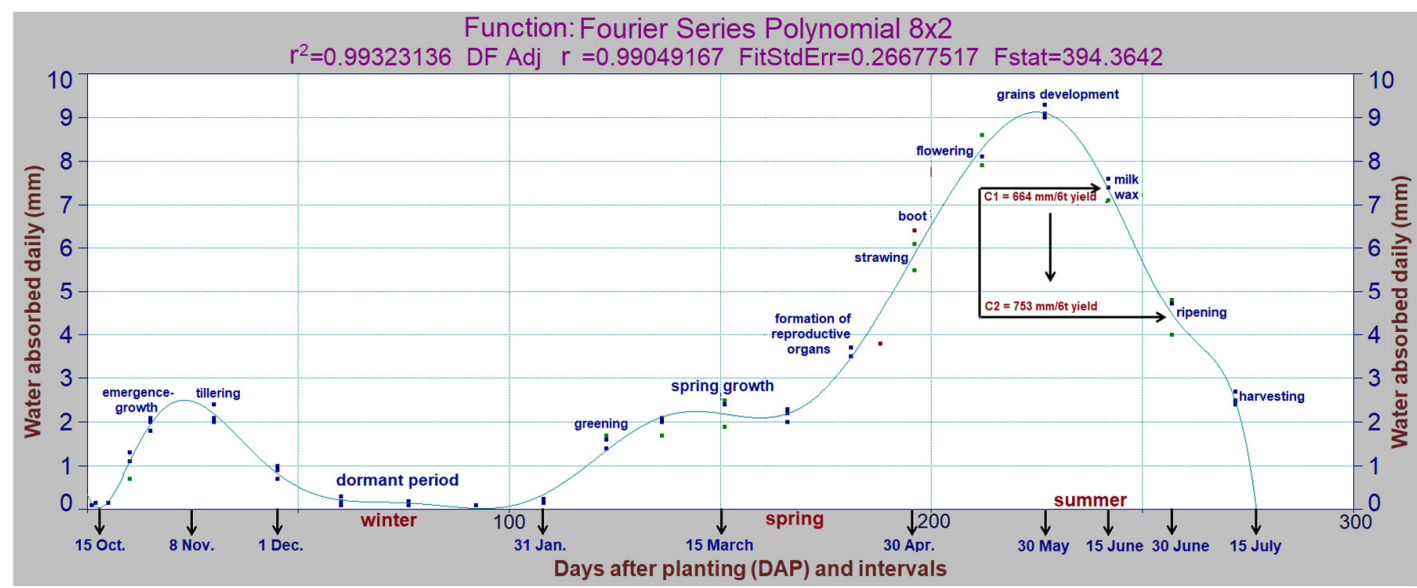

Figure 1. Water consumption of wheat $(\mathrm{mm})$ during the growing season in a favorable area Own data, processed using the Table Curve 2D analysis program

From Figure 1 it results that the total water consumption of wheat crops in Romania during the period from sowing to maturation-ripening (at about $14 \%$ humidity) is of $7530 \mathrm{~m}^{3} \mathrm{ha}^{-1}$ for a yield of 7.0-7.5 $\mathrm{t} \mathrm{ha}^{-1}$, resulting an indicator of $1004-1075 \mathrm{~m}^{3}$ water $\mathrm{t}^{-1}$ grains. Of these, $740 \mathrm{~m}^{3} \mathrm{ha}^{-1}$ were consumed since autumn, in a period of about 56 days, until the appearance of frosts. During the winter, both transpiration and evaporation were negligible, immeasurable for 35-40 days, on average. In the agricultural year 2019-2020, in the second part of January there were temperatures high enough to interrupt the crop wintering, which became active earlier than usual. Starting with the second decade of February 2020, the daily consumption reached 1$2 \mathrm{~mm}$ day $^{-1}$, and from mid-March it increased gradually, going through all the phases of wheat development, reaching the maximum consumption of $8-9 \mathrm{~mm} \mathrm{day}^{-1}$ from flowering until the formation of grains and then decreased to 6-7 $\mathrm{mm} \mathrm{day}^{-1}$ until the milk-wax phase and keep decreasing until ripening and, then, harvesting. By using the integral calculation, the water consumption of the crop for the desired period have been obtained. 


$$
\text { Autumn consumption }=\int_{1}^{56} f x(d x)=74 \mathrm{~mm}=740 \mathrm{~m}^{3} \mathrm{ha}^{-1}
$$

If the water consumption in autumn is higher, it means that the plants are much more developed than they should be, so they could be subject to disease and pests ever since autumn, and the excess of consumed water is unproductive, since plants are forced to pass, during winter, by the vernalization process, in order to differentiate their reproductive organs.

In Figure 2 the depletion of water in the soil only during the period of active vegetation, from spring to maturity, it's shown. The calculation has been made taking into account the consumption for each half of month, starting with the second half of January and until the beginning of July. In total, 13 halves of months, i.e. six and a half months ( 195 days $\pm 5 \%)$.

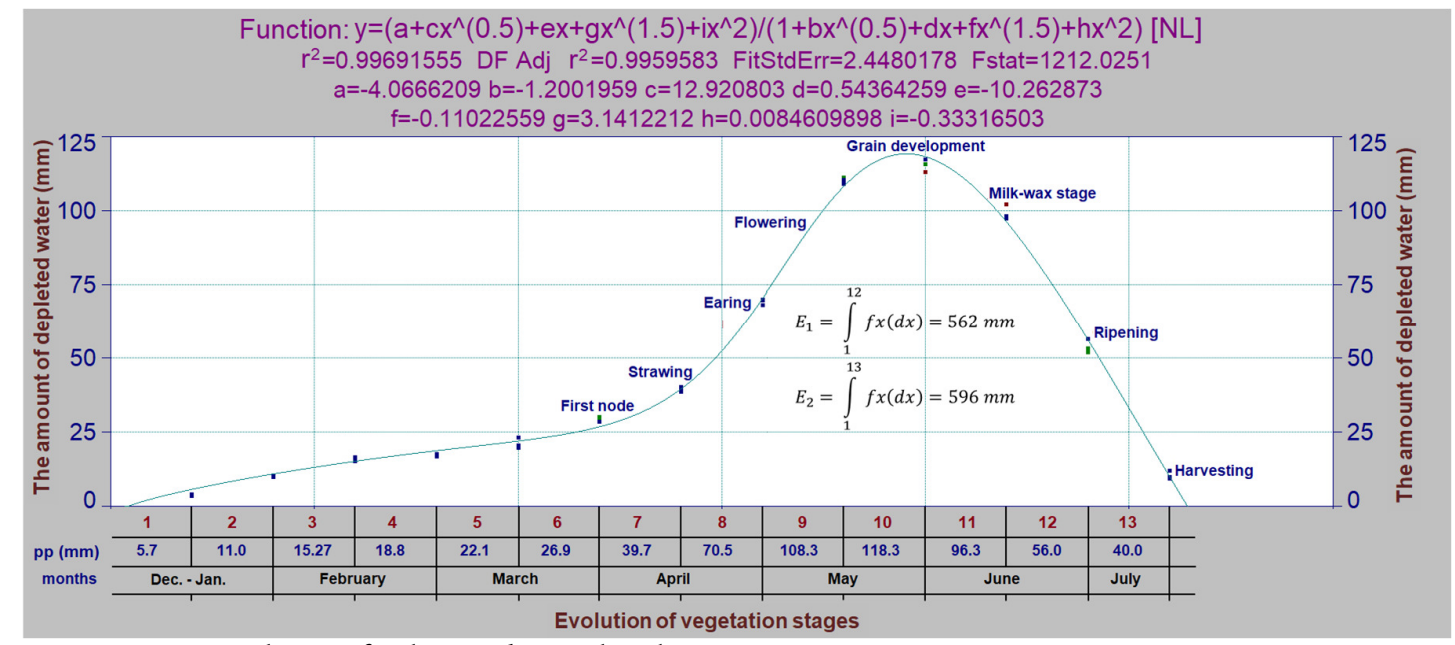

Figure 2. Depletion of soil water during the wheat growing season

Own data, processed using the Table Curve 2D analysis program

From Figure 2, created after the USDA model (Erie et al., 1981), we see that, on a multiannual average, the extraction of water from the soil by evaporation and transpiration $(\mathrm{E}+\mathrm{T})$ begins in December - January (insignificant) and becomes significant in March, at $49 \mathrm{~mm} \mathrm{month}^{-1}$ (twice as much as in February). The extraction of water from the soil increases sharply starting with April and continuing in May and June. The maximum extraction by $\mathrm{E}+\mathrm{T}$ is achieved at the time of 8.25 halves of month of consumption and is $41.1 \mathrm{~mm}$ $=411 \mathrm{~m}^{3}$ over this 15 -day interval. Practically, this means the first half of June, when the flowering and grain formation take place, after which the water left from the soil by evapotranspiration is reduced, and if the soil, exceptionally, is wet, it's oriented towards evaporation.

From this point forward, own measurements and those of the cited researchers cease. The maximum of depleted water was calculated by applying the derivative at the maximum point of the function in Figure 2 . The total amount of depleted water was found by calculating the integral under the curve for the entire depletion period, i.e.:

$$
\begin{aligned}
& \int_{1}^{13} f x(d x)=596 m m=5960 \mathrm{~m}^{3} h a^{-1} \text { (until rippening) } \\
& \int_{1}^{12} f x(d x)=562 \mathrm{~mm}=5620 \mathrm{~m}^{3} \mathrm{ha}^{-1} \text { (until wax stage) }
\end{aligned}
$$


Comparing these data with those of Figure 1, it results that the water extracted by plants from the soil through $\mathrm{E}+\mathrm{T}$ during spring was lower than the water actually consumed, the values being the following: 753$774>596,679>596$, the difference being of $83 \mathrm{~mm}=830 \mathrm{~m}^{3} \mathrm{ha}^{-1}$.

It is assumed that, in conditions of lack of surface runoff during periods of severe drought, such as that of 2020, the plants have appealed to condensation water, obtained by dew, due to the high alternation between day and night time heat values, which according to our measurements it could have brought, in about 35 days with good condensation, about $70 \mathrm{~mm}$, i.e. between $1-2 \mathrm{~mm}$ day ${ }^{-1}$. This volume is insignificant for the soil, but very important for the survival of the crop between two periods of small rains, up to the coming of a heavier rain.

In Figure 3, inspired by Shankar et al. (2012) and Erie et al. (1981), it's presented the scheme of a soil water depletion model, given that the soil is periodically supplied with water from precipitation, at intervals that didn't allow the soil moisture to decrease (\%). Under these conditions, $87 \%$ of the water removed from the soil was in the $0-90 \mathrm{~cm}$ depth horizon, $96 \%$ at a depth of $0-120 \mathrm{~cm}, 99 \%$ at $0-150 \mathrm{~cm}$ and $100 \%$ at $0-180$ $\mathrm{cm}$. In has also been noticed, on the soil profile, that the root system is rarely found at depths greater than 100 $\mathrm{cm}$, from where about $90 \%$ of the soil water is extracted by $\mathrm{E}+\mathrm{T}$. So, it's very important for the rains to bring enough water to moisten $100-150 \mathrm{~cm}$ soil, in depth. Deeper water can be lost.

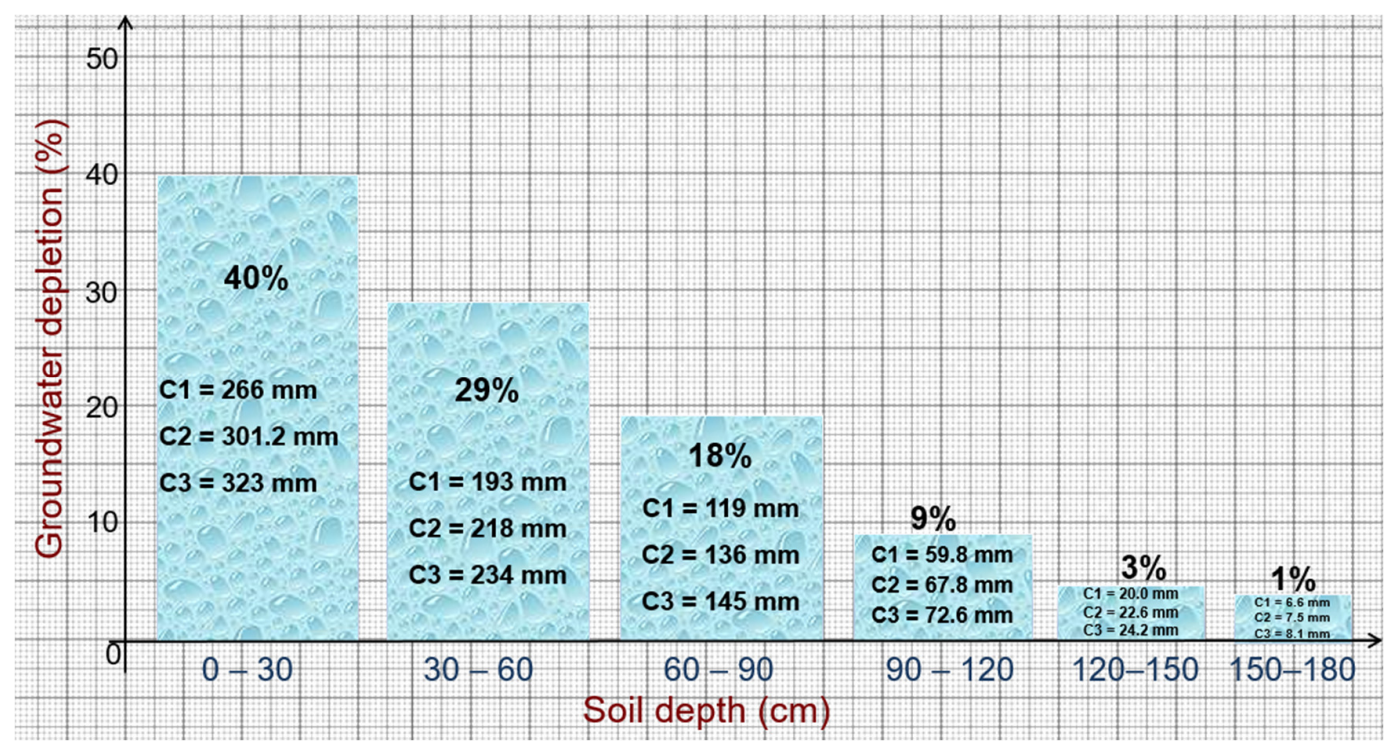

Figure 3. Model of soil water depletion, by mixed consumption $(E+T)$, for medium soils and different consumption phases

It's emphasized from Figure 1, Figure 2 and Figure 4 that there is a variable parallelism between the calculations regarding the water consumption of wheat plants (crops) and the amount of water actually extracted. The calculations were performed according to data collected from several authors (Berca et al., 2012; Hoekstra and Hung, 2002; Liess, 2017; Shankar et al., 2012; Smith et al., 2002).

Assuming that the processed data are as close as possible to the reality in the field, it's noticed that, at the beginning of vegetation, almost all of the water consumed by plants is delivered by the soil. The difference between consumption and what comes out of the soil increases constantly until June, when this difference is the highest (about $970 \mathrm{~m}^{3} \mathrm{ha}^{-1}$ ). The obvious question arises: if the crop consumes more than it takes out of the soil, what other source of water completes the deficit? 


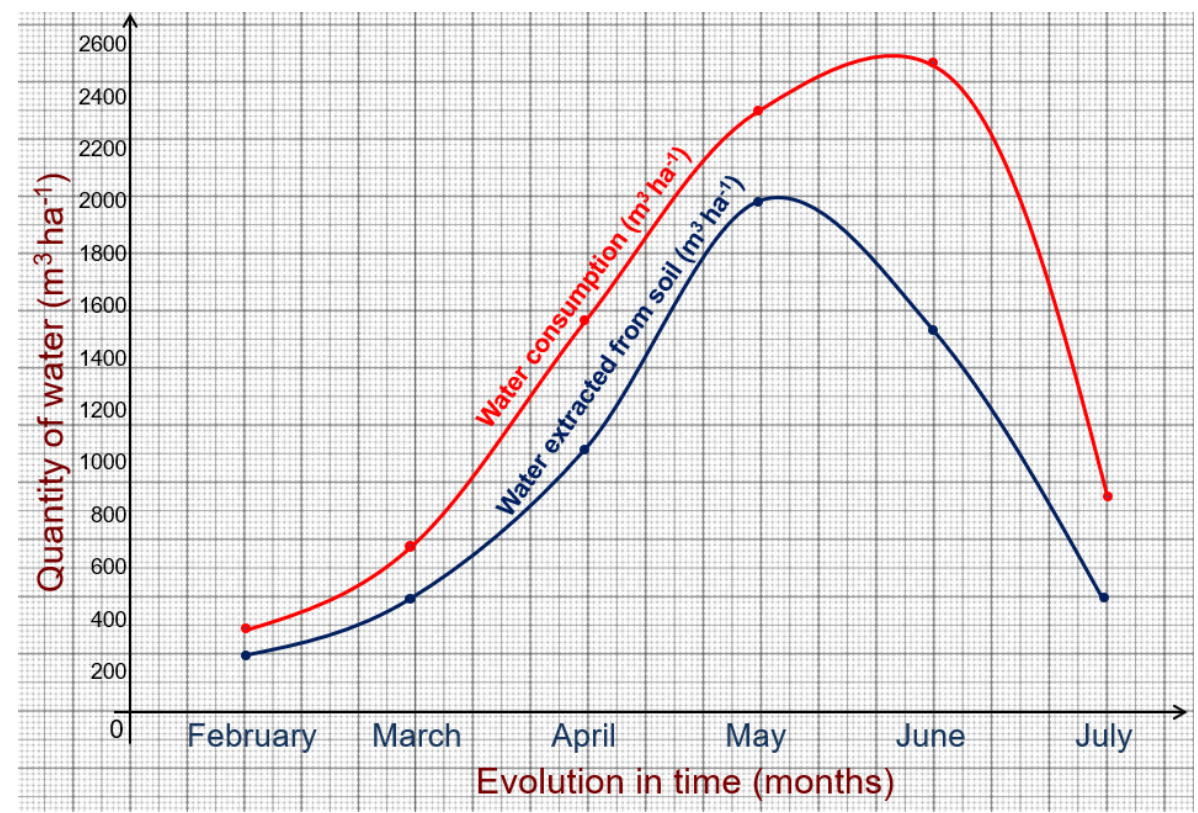

Figure 4. Indicative scheme of the difference in water actually consumed and water extracted from the soil, both by evaporation and transpiration (PET)

There is, given the lack of groundwater and the circulation of water through the soil, generated by slopes, a source that we consider very important, especially in the spring, when the difference in positive temperatures between day and night is very large $\left(10-20^{\circ} \mathrm{C}\right)$. At such differences there is water condensation, forming abundant dew on the leaves of plants. The water is then directed to the base of the stem and it helps the crop to survive until the first significant rainfall (Figure 5).

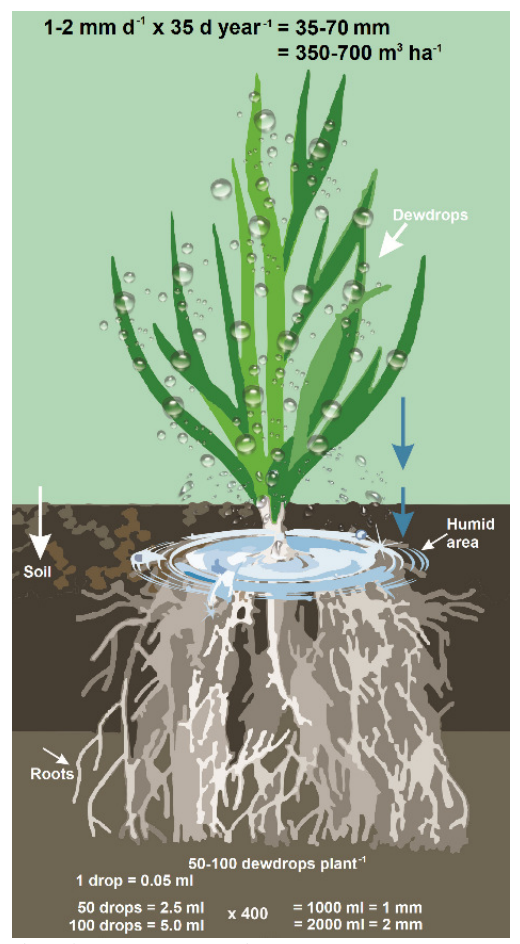

Figure 5. Condensation, dew and soil moisture in the spring 
If the autumn and winter are rich in rainfall, soils can form a water reserve - between $900 \mathrm{~m}^{3} \mathrm{ha}^{-1}$ on shallow soils and about $2000 \mathrm{~m}^{3} \mathrm{ha}^{-1}$ on clay soils. In south Romania crops could count on about 1500-1800 $\mathrm{m}^{3} \mathrm{ha}^{-1}$, this being the useful reserve of water. This amount of water could ensure the consumption of plants in March and April, after which the lack of rain would quickly lead to drought, which affects the plants exactly during the formation of straw and the formation of reproductive organs, when the consumption is very high.

In order for this consumption (shown in Figure 1) to be achieved by plants without losing energy, it would be necessary to maintain the soil above the capillary breaking moisture index. It means that in MarchApril it should also rain at intervals of 20 days, at least $150 \mathrm{~mm}$ of precipitation, which is quite difficult to obtain, especially in southern Romania. Let's not forget the target of $7500 \mathrm{~kg}$ wheat ha ${ }^{-1}$. The rains that fall in May-June are, usually, enough to ensure the consumption of plants, while those of July are no longer necessary for the wheat crops.

\section{The situation in the agricultural year 2019-2020 in southern Romania}

Results obtained in experimental fields and in production conditions in Modelu (Calarasi county) and in Calomfiresti (Teleorman county) were calculated. These results represent the average of six premium wheat varieties. It's to be mentioned that the 2018-2019 agricultural year was also very dry and didn't leave in soil a convenient water reserve in autumn 2019.

According to our determinations, at the end of 2019 the water reserve in the soil (at $150 \mathrm{~cm}$ depth) was about $610 \mathrm{~m}^{3} \mathrm{ha}^{-1}$ in Modelu and $1030 \mathrm{~m}^{3} \mathrm{ha}^{-1}$ in Calomfiresti. From January to June 2020, $253 \mathrm{~mm}$ of rainfall were recorded in Modelu and $309 \mathrm{~mm}$ in Calomfiresti, so a total of $3140 \mathrm{~m}^{3} \mathrm{ha}^{-1}$ of water was available in Modelu, respectively $4020 \mathrm{~m}^{3} \mathrm{ha}^{-1}$ in Calomfiresti. However, the plus of $900 \mathrm{~m}^{3} \mathrm{ha}^{-1}$ for the entire vegetation period doesn't explain a yield difference of $2730 \mathrm{~kg}_{\text {wheat }} \mathrm{ha}^{-1}$ (Table 1). From the entire equation, the yield surplus from Calomfiresti appears difficult to explain at first sight. The evapotranspiration was the same in both locations. The difference in useful water reserve (about $900 \mathrm{~m}^{3} \mathrm{ha}^{-1}$ in addition to Calomfiresti) explains an increase of about $1000 \mathrm{~kg} \mathrm{ha}^{-1}$. The remaining $1730 \mathrm{~kg} \mathrm{ha}^{-1}$ can only be explained by a better distribution of the rains.

Table 1. Meteorological data (rainfall, evapotranspiration) explaining the wheat yields in southern Romania, in the 2019-2020 agricultural year (average for six varieties)

\begin{tabular}{|c|c|c|c|c|c|c|c|c|}
\hline \multirow{3}{*}{ Months } & \multicolumn{3}{|c|}{ Modelu - Calarasi } & \multicolumn{3}{|c|}{ Calomfiresti - Teleorman } & \multicolumn{2}{|c|}{ Average pp. 1961-1990 } \\
\hline & Precip. & ET & Difference & Precip. & ET & Difference & Modelu & Calomfiresti \\
\hline & \multicolumn{8}{|c|}{$\mathrm{mm}$} \\
\hline January & 2.0 & 20.3 & -18.3 & 3.2 & 19.5 & -16.3 & 31.0 & 36.9 \\
\hline February & 30.0 & 37.9 & -7.9 & 49.2 & 35.8 & +13.4 & 30.4 & 31.8 \\
\hline March & 16.0 & 62.4 & -46.6 & 65.2 & 55.9 & -9.3 & 30.9 & 34.5 \\
\hline April & 5.0 & 117.9 & -112.9 & 16.1 & 112.5 & -96.4 & 35.6 & 44.5 \\
\hline May & 83.0 & 130.6 & -47.6 & 69.6 & 126.2 & -56.6 & 57.8 & 54.4 \\
\hline June & 117.0 & 97.4 & +19.6 & 105.4 & 123.5 & -18.1 & 63.3 & 68.1 \\
\hline Amount pp. & 253.0 & 466.5 & -213.7 & 308.7 & 473.4 & -183.3 & 249.0 & 270.2 \\
\hline $\begin{array}{l}\text { Average yield } \\
\left(\mathrm{kg} \mathrm{ha}^{-1}\right)\end{array}$ & \multicolumn{3}{|c|}{3150} & \multicolumn{3}{|c|}{$5880^{* * *}$} & & \\
\hline
\end{tabular}

${ }^{* * *}$ It notes that there is a very significant difference, comparing with the control version, according to the variance analysis, for a limit difference of 5\% (LD5\%).

January, March and April were extremely harsh in terms of rainfall. March and especially April are the months in which wheat crop has an intense vegetative growth, including the formation of straw, knots, the reproductive organs differentiation and the beginning of the ear formation. In 2019-2020, the drought in Calarasi led to the earlier formation of fewer spikelet per ear and, so, to a reduce number of grains per ear. In Calomfiresti were, in March and April, at least three times more rains than in Modelu, where it rained in second 
part of May, when the wheat crop was already partially compromised. Also, water consumption in Calomfiresti was dominated by the productive consumption component (" $\mathrm{T}$ " - transpiration), the crops were well coagulated, covering the soil, reducing significantly the unproductive consumption component (" $E$ " evaporation). At Modelu was exactly the opposite.

The very severe drought of winter-spring, associated with very high temperatures during this period, led to the rapid depletion of water, to the decrease of soil moisture and to the inhibition of crop development.

If the plants still resisted, this was due to water condensation on the plants (dew), very abundant in the late winter - early spring months and which brought between 1-2 $1 \mathrm{~m}^{-2}=10-20 \mathrm{~m}^{3} \mathrm{ha}^{-1} \mathrm{day}^{-1}$. Water reached the base of the plant, helping it to survive. Between 50 and 110 dew drops were formed on each plant, which at an average of 400 plants $\mathrm{m}^{-2}$ means a total of $1.0-2.2 \mathrm{~m}^{-2}[0.05 \times(50 \ldots 110) \times 400]$. It turns out that, in this way, the crop receives between 10 and $22 \mathrm{~m}^{3} \mathrm{ha}^{-1}$ for the days with the highest and best condensation.

In March-April, some small rains, of 3-4 mm, were added to the dew amount. The water remained in the surface layer, where the plant roots developed, in round balloons form, looking for the little water that came from above. The roots couldn't penetrate deeper than $15-20 \mathrm{~cm}$ due to lack of water. On the other hand, in Calomfirești the roots were normally developed, the water reserve being present up to $75 \mathrm{~cm}$ in depth (Figure 6, A and B).

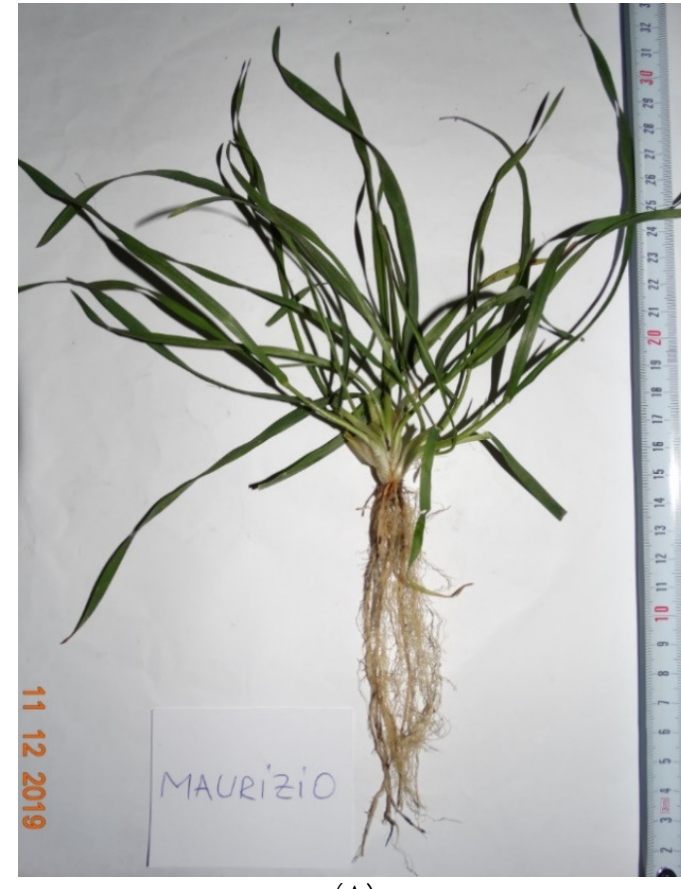

(A)

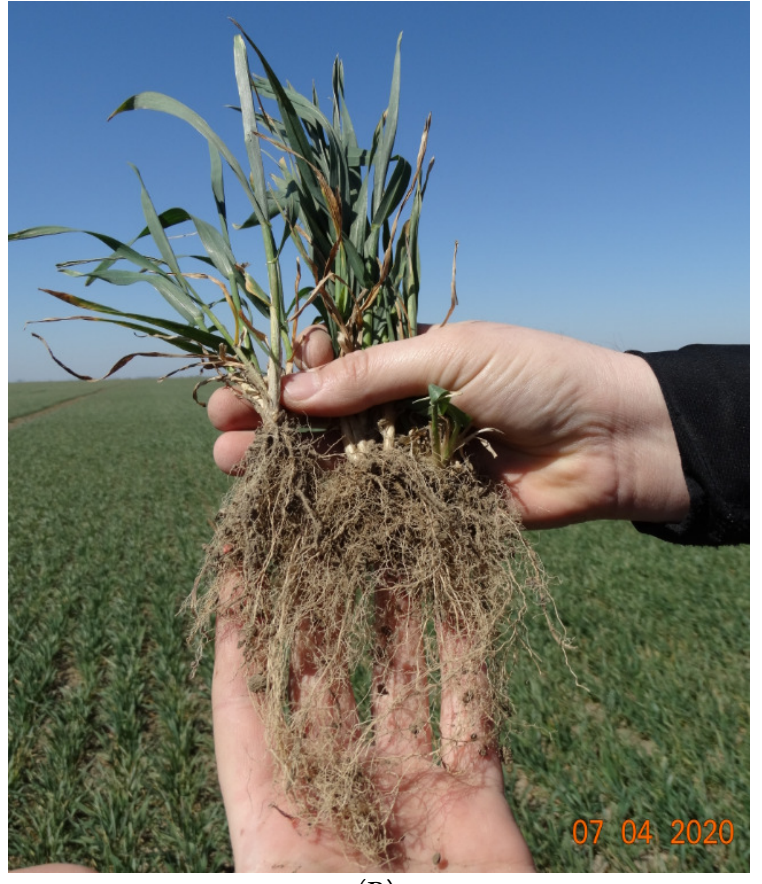

(B)

Figure 6. Comparison between two root system development; (A) In a soil with a good water reserve (Calomfiresti, late autumn 2019); (B) In a soil poor in water (Modelu, spring 2020)

Own pictures, made at the two-research location, in the mentioned dates

Remaining of the roots in the soil shallow layer is useful as long as we have dew (condensation). With increasing temperatures (warm - heat) and reduced relative humidity dew no longer forms and, in the absence of rain, plants enter in high stress, the metabolism is dramatically reduced and, if the phenomenon occurs in April or early May, when the production elements (ears, spikelets, grains) are in formation, they are highly reduced or not formed at all. Yield is compromised or quantitatively and qualitatively reduced. This was the situation in the agricultural year 2019-2020 on about 1 million ha, where yields between 0 and $2500 \mathrm{~kg} \mathrm{ha}^{-1}$ were obtained. 
With wheat varieties that are more drought tolerant, making water savings (Tamino and Bitop, for example), up to $3100-3500 \mathrm{~kg} \mathrm{ha}^{-1}$ have been obtained. However, there is a positive correlation during drought, between the specific water consumption of the soil, the yield and its quality. A pattern of wheat crop behavior in southern Romania is presented in Figure 7, confirming the above, through calculations and observations.

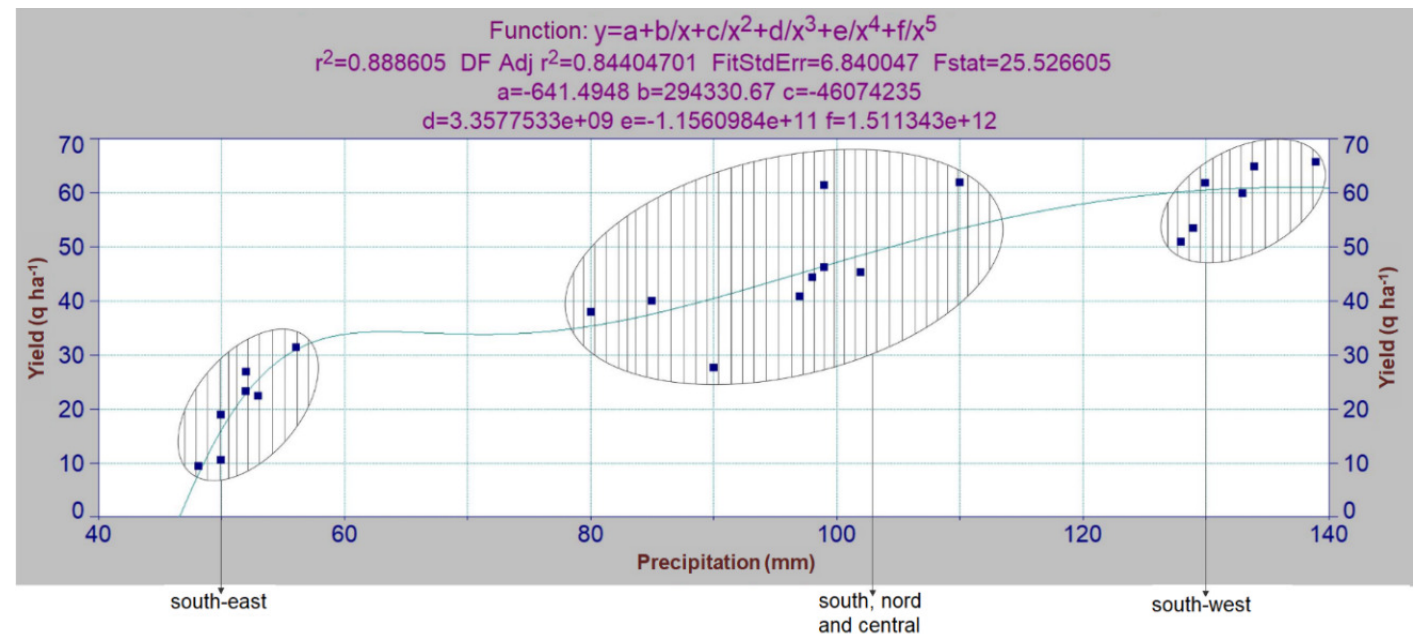

Figure 7. Correlation between the amount of precipitation and the wheat yields obtained in different regions from Romania, with premium wheat varieties

Own data, processed using the Table Curve $2 \mathrm{D}$ analysis program

\section{Conclusions}

The water consumption of wheat crop for a yield of 6-7 $\mathrm{t} \mathrm{ha}^{-1}$ is between 6000 and $7500 \mathrm{~m}^{3} \mathrm{ha}^{-1}$, i.e. about $1000 \mathrm{~m}^{3} \mathrm{t}^{-1}$ of grains. Precipitations that normally fall in Romania can ensure average yields of 6-7 $\mathrm{t} \mathrm{ha} \mathrm{h}^{-1}$ with the current varieties and technologies. Groundwater supply and irrigation can correct the lack of water for optimal consumption. It is safer to correct the necessary water consumption through irrigation, where possible.

Technologies can have an essential contribution to water supply for crops, by conserving the useful reserve and reducing evaporation (unproductive consumption), in favor of transpiration (productive consumption). The preceding plant and the basic field works can also make significant differences in preserving useful water for plants (10-30\%). Fertilizers application, especially nitrogen, to the required doses $(20-24 \mathrm{~kg} \mathrm{~N}$ $\mathrm{t}^{-1}$ wheat) lead to a good coverage of the land with plants, to the change of the transpiration-evaporation ratio in favor of transpiration, as the productive component of PET. Fighting diseases and especially weeds leaves more water in the soil, available to wheat plants. Dew (condensation on plants) plays an important role in supporting plants in the spring, in conditions of severe drought, especially at ground level.

Also, choosing annually wheat varieties with low specific water consumption and higher tolerance to water stress is a wise decision for farmers. All additional measures that reduce evaporation at the soil surface, such as reducing winds through protective curtains, retaining snow on cultivated fields using wind protecting fences, mulching, green manure, fallow ground and others, there are also elements to optimize the regulation of water retention in the soil and its economical consumption by plants. Using optimal technologies, wheat crop will become quite productive even in drought areas. 


\section{Authors' Contributions}

All authors read and approved the final manuscript.

\section{Acknowledgements}

This research received no specific grant from any funding agency in the public, commercial, or not-forprofit sectors.

\section{Conflict of Interests}

The authors declare that there are no conflicts of interest related to this article.

\section{References}

ACES (2018). Small grain forages for New Mexico. Cooperative Extension Services. College of Agricultural, Consumer and Environmental Sciences. Circular 630. Retrieved 2021 January 27 from https://aces.nmsu.edu/pubs/_circulars/CR630.pdf

Allen RG, Pereira LS, Raes D, Smith M (1998). Crop evapotranspiration - Guidelines for computing crop water requirements - FAO Irrigation and drainage paper No. 56. Retrieved 2021 February 17 from http://www.climasouth.eu/sites/default/files/FAO\%2056.pdf

Anwaar AF, Perveen R, Mansha MZ, Abid M, Sarwar ZM, Aatif HM, ... Khan KA (2020). Assessment of grain yield indices in response to drought stress in wheat (Triticum aestivum L.). Saudi Journal of Biological Sciences 27(7):1818-1823. https://doi.org/10.1016/j.sjbs.2019.12.009

Beauchamp J (2006). L'eau et le sol [Water and soil]. Universite de Picardie Jules Verne. Retrieved 2021 January 27 from https://www.u-picardie.fr/beauchamp/mst/eau-sol.htm

Berca M (2011). Agrotehica, transformarea moderna a agriculturii [Agrotechnics, the modern transformation of agriculture]. Bucharest, Romania. Ceres Publishing House.

Berca M, Robescu VO, Buzatu SC (2012). Managementul mediului [Environment management]. Bucharest, Romania. Ceres Publishing House.

Blaga G, Filipov F, Rusu I, Udrescu S, Vasile D (2005). Pedologie [Pedology]. Cluj-Napoca, Romania. AcademicPres Publishing House.

Chowdhury S, Al-Zahrani M, Abbas A (2016). Implications of climate change on crop water requirements in arid region: An example of Al-Jouf, Saudi Arabia. Journal of King Saud University - Engineering Sciences 28(1):21-31. https://doi.org/10.1016/j.jksues.2013.11.001

Cojocaru O (2016). Insusirile fizile ale solurilor din arealul rural si evaluarea expunerii lor la eroziune [Physical properties of soils in rural area and their exposure assessment of erosion]. Revista de Stiinta, Inovare, Cultura si Arta 'Akademos' 40(1):81-84.

Cui Y, Jiang S, Feng P, Jin J, Yuan H (2018). Winter wheat evapotranspiration estimation under drought stress during several growth stages in Huaibei Plain, China. Water 10(9):1208. https://doi.org/10.3390/w10091208

da Silva TJA, Bonfim-Silva EM, Fenner W, Duarte T, José JV, Castanon THFM (2020). Evapotranspiration and crop coefficients in two irrigated wheat cultivars. Revista Brasileira de Engenharia Agricola e Ambiental 24(4):252257. http://dx.doi.org/10.1590/1807-1929/agriambi.v24n4p252-257

Drerup P, Brueck H, Scherer HW (2017). Evapotranspiration of winter wheat estimated with the FAO 56 approach and NDVI measurements in a temperate humid climate of NW Europe. Agricultural Water Management 192:180188. https://doi.org/10.1016/j.agwat.2017.07.010

Duggan BL, Domitruk DR, Fowler DB (2000). Yield component variation in winter wheat grown under drought stress. Canadian Journal of Plant Science 80(4):739-745. https://doi.org/10.4141/P00-006 
Erie LJ, French OF, Bucks DA, Harris K (1981). Consumptive use of water by major crops in the southwestern United States. USDA, Conservation Research Report No. 29. Retrieved 2021 January 27 from https://cals.arizona.edu/crops/irrigation/consumuse/conusefinal.pdf

Fan Z, Chai Q, Huang G, Yu A, Huang P, Yang C, ... Liu H (2013). Yield and water consumption characteristics of wheat/maize intercropping with reduced tillage in an Oasis region. European Journal of Agronomy 45:52-58. https://doi.org/10.1016/j.eja.2012.10.010

Fletcher A, Christopher J, Hunter M, Rebetzke G, Chenu K (2018). A low-cost method to rapidly and accurately screen for transpiration efficiency in wheat. Plant Methods 14:77. https://doi.org/10.1186/s13007-018-0339-y

Giunta F, Motzo R, Deidda M (1993). Effect of drought on yield and yield components of durum wheat and triticale in a Mediterranean environment. Field Crops Research 33(4):399-409. https://doi.org/10.1016/03784290(93)90161-F

He L, Cleverly J, Chen C, Yang X, Li J, Liu W, Yu Q (2014). Diverse responses of winter yield and water use to climate change and variability on the semiarid Loess Plateau in China. Agronomy Journal 106(4):1169-1178. https://doi.org/10.2134/agronj13.0321

Hoban A (2008). Aspecte privind indicii hidro-fizici - densitatea aparenta a solului in solarul experimental din Someseni, Cluj-Napoca [Aspects regarding the hydrophysical indices - apparent soil density in experimental solar from Someseni, Cluj-Napoca]. Agricultura - Stiinta si practica 65(1-2):49-51. http://dx.doi.org/10.15835/arspa.v65i1-2.2788

Hobbs EH, Krogman KK (1974). Evapotranspiration of wheat, oats and barley. Canadian Journal of Plant Science 54(1):23-27. https://doi.org/10.4141/cjps74-004

Hoekstra AY, Hung PQ (2002). Virtual water trade - A quantification of virtual water flows between nations in relation to international crop trade. Value of Water Research Report Series No. 11. IHE Delft. Retrieved 2021 January 27 from https://www.waterfootprint.org/media/downloads/Report11.pdf

Jamieson PD, Martin RJ, Francis GS (1995). Drought influences on grain yield of barley, wheat and maize. New Zealand Journal of Crop and Horticultural Science 23(1):55-66. https://doi.org/10.1080/01140671.1995.9513868

Kenjabaev S, Frede HG, Begmatov I, Isaev S, Matyakubov B (2020). Determination of actual crop evapotranspiration (ETC) and dual crop coefficients (KC) for cotton, wheat and maize in Fergana Valley: integration of the FAO56 approach and budget. Journal of Critical Reviews 7(5):340-349. http://dx.doi.org/10.31838/jcr.07.05.67

Khan S, Anwar S, Shaobo Y, Gao Z, Sun M, Ashraf MY, ... Yang Z (2020). Soil water consumption, water use efficiency and winter wheat production in response to nitrogen fertilizer and tillage. PeerJ 8:e8892. https://doi.org/10.7717/peerj.8892

Li H, Zheng L, Lei Y, Li C, Liu Z, Zhang S (2008). Estimation of water consumption and crop water productivity of winter wheat in North China Plain using remote sensing technology. Agricultural Water Management 95(11):1271-1278. https://doi.org/10.1016/j.agwat.2008.05.003

Liess C (2017). Virtuelles Wasser und Wasserfußabdruck [Virtual water and water footprint]. Wasserzeichen 45:21-26. Retrieved $2021 \quad$ March 2 from https://stroemungsinstitut.de/wpcontent/uploads/2017/06/WZ45_Virtuelles_Wasser.pdf

Lu Y, Ma D, Chen X, Zhang J (2018). A simple method for estimating field crop evapotranspiration from pot experiments. Water 10(12):1823. https://doi.org/10.3390/w10121823

MMGA (2005). Code of good agricultural practices (in Romanian). Bucharest. Retrieved 2021 January 28 from https://www.icpa.ro/documente/coduri/cbpaRO.pdf

Moutonnet P (2002). Yield response factors of field crops to deficit irrigation. Deficit Irrigation Practices - FAO Water Reports No. 22. Retrieved 2021 January 27 from http://www.fao.org/3/Y3655E/y3655e04.htm\#d

Muratoglu A (2020). Assessment of wheat's water footprint and virtual water trade: a case study for Turkey. Ecological Processes 9:13. https://doi.org/10.1186/s13717-020-0217-1

Nulsen RA, Baxter IN (1987). Water use by some crops and pastures in the southern agricultural areas of Western Australia. Department of Agriculture and Food, Western Australia, Perth. Report 32. ISSN 0729-3135. Retrieved 2021 January 27 from https://core.ac.uk/download/pdf/234608573.pdf

Patel NR, Rakhesh D, Mohammed AJ (2010). Mapping of regional evapotranspiration in wheat using Terra/MODIS satellite data. Hydrological Sciences Journal 51(2):325-335. https://doi.org/10.1623/hysj.51.2.325

Pradham GP, Prasad PVV, Fritz AK, Kirkham MB, Gill BS (2012). Effects of droughts and high temperature stress on synthetic hexaploidy wheat. Functional Plant Biology 39(3):190-198. https://doi.org/10.1071/FP11245 
Qaseem MF, Qureshi R, Shaheen H (2019). Effects of pre-anthesis drought, heat and their combination on the growth, yield and physiology of diverse wheat (Triticum aestivum L.) genotypes varying in sensitivity to heat and drought stress. Scientific Reports 9:6955. https://doi.org/10.1038/s41598-019-43477-Z

Ray RL, Fares A, Risch E (2018). Effects of drought on crop production and cropping areas in Texas. Agricultural \& Environmental Letters 3(1):170037. https://doi.org/10.2134/ael2017.11.0037

Sang X, Wang D, Lin X (2016). Effects of tillage practices on water consumption characteristics and grain yield of winter wheat under different soil moisture conditions. Soil and Tillage Research 163:185-194. https://doi.org/10.1016/j.still.2016.06.003

Scott A, Niece B, Mesbah A (2019a). Irrigated wheat variety trial. NMSU Agricultural Science Center at Clovis. Retrieved 2021 January 27 from https://clovissc.nmsu.edu/documents/2019-clovis-irrigated-wheat-summary-andresults.pdf

Scott A, Niece B, Mesbah A (2019b). Dryland wheat variety trial. NMSU Agricultural Science Center at Clovis. Retrieved 2021 January 27 from https://clovissc.nmsu.edu/documents/2019-clovis-dryland-wheat-summary-andresults.pdf

Scradeanu D, Gheorghe A (2007). Hidrogeologie generala [General hydrogeology]. Bucharest, Romania. University of Bucharest Publishing House.

Shankar V, Hari Prasad KS, Ojha CSP, Govindaraju RS (2012). Model for nonlinear root water uptake parameter. Journal of Irrigation and Drainage Engineering 138(10):905-917. https://doi.org/10.1061/(ASCE)IR.19434774.0000469

Shayanmehr S, Henneberry SR, Sabouni MS, Foroushani NS (2020). Drought, climate change and dryland wheat yield response: an econometric approach. International Journal of Environmental Research and Public Health 17(14):5264. https://doi.org/10.3390/ijerph17145264

Shen X, Wang G, Zeleke KT, Si Z, Chen J, Gao Y (2020). Crop water production functions for winter wheat with drip fertigation in the North China Plain. Agronomy 10(6):876. https://doi.org/10.3390/agronomy10060876

Smith M, Kivumbi D, Heng LK (2002). Use of the FAO CROPWAT model in deficit irrigation studies. Deficit Irrigation Practices - FAO Water Reports No. 22. Retrieved 2021 January 27 from http://www.fao.org/3/Y3655E/y3655e05.htm\#e

Tyagi NK, Sharma Dk, Luthra Sk (2000). Evapotranspiration and crop coefficients of wheat and sorghum. Journal of Irrigation and Drainage Engineering 126(4):215-222. https://doi.org/10.1061/(ASCE)07339437(2000)126:4(215)

Yu H, Zhang Q, Sun P, Song C (2018). Impact of droughts on winter wheat yield in different growth stages during 20012016 in Eastern China. International Journal of Disaster Risk Science 9:376-391. https://doi.org/10.1007/s13753-018-0187-4

Zampieri M, Ceglar A, Dentener F, Toreti A (2017). Wheat yield loss attributable to heat waves, drought and water excess at the global, national and subnational scales. Environmental Research Letters 12(6):064008. https://doi.org/10.1088/1748-9326/aa723b

Zhang S, Lövdahl L, Grip H, Tong Y, Yang X, Wang Q (2009). Effects of mulching and catch cropping on soil temperature, soil moisture and wheat yield on the Loess Plateau of China. Soil and Tillage Research 102(1):7686. https://doi.org/10.1016/j.still.2008.07.019

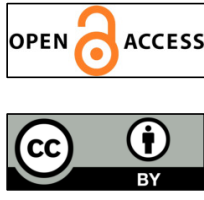

The journal offers free, immediate, and unrestricted access to peer-reviewed research and scholarly work. Users are allowed to read, download, copy, distribute, print, search, or link to the full texts of the articles, or use them for any other lawful purpose, without asking prior permission from the publisher or the author.

License - Articles published in Notulae Botanicae Horti Agrobotanici Cluj-Napoca are Open-Access, distributed under the terms and conditions of the Creative Commons Attribution (CC BY 4.0) License.

(c) Articles by the authors; UASVM, Cluj-Napoca, Romania. The journal allows the author(s) to hold the copyright/to retain publishing rights without restriction. 